\title{
Developing Leadership Competency: Competitive and Sustainable Human Resource Management
}

\author{
Lily Rachmawaty Pulubuhu \\ Makassar Aviation Politechnics, South Sulawesi, Indonesia. \\ E-mail: lilypulubuhu@gmail.com
}

\begin{abstract}
In welcoming the era of industrial revolution 4.0 today, human resource management has a central position in realizing development performance. This research is an explanatory research that explains the causal relationship of variables through hypothesis testing using a conceptual approach. It uses a qualitative approach by looking at phenomena and to measure the effect of leadership competency and quality in human resource management. The results indicated that leadership competency and quality simultaneously had a significant and positive effect on competitive and sustainable human resource management. Human resource development in organizations is an integral form of business development both concerning human resources as individuals and as a system, as well as organizations as human resource containers to meet the needs of any organization.
\end{abstract}

Keywords: Human Resources; Leadership; Management; Sustainable; Competitiveness; Quality

DOI: $10.7176 / \mathrm{EJBM} / 12-20-10$

Publication date:July $31^{\text {st }} 2020$

\section{Introduction}

Leadership occupies a strategic position among other resources. Without leadership competence and quality, other resources cannot be utilized optimally, especially if managed to produce a product (Ellitan, 2002). But on a practical level, there are still many companies that do not realize the importance of competency and leadership qualities in human resource management for the survival of the company.

In welcoming the era of industrial revolution 4.0 today, we cannot reject that human resource management has a central position in realizing development performance. However, advances in technology today, human factors still play an important role for the success of an organization. It can even be said that management is essentially human resource management or it is identical to management itself, placing humans in their function as development resources. One of the important resources in management is human resources (Ghoniyah \& Masurip, 2011). The importance of human resources needs to be recognized by all levels of management.

Today, competition in the business world requires every organization to make changes in order to continue to grow and survive. These changes can be started from the individual then to the group. Change must be made first by the leadership, because the leader is an example in the organization. Therefore, organizations must have leaders who not only lead, but also are able to move their organizations to change.

The survival of an organization depends on its leader. The leader becomes one of the determining indicators of success in achieving organizational goals. Reformed leaders must be sensitive to change, be able to analyze what are the weaknesses and strengths of both internal and external organizations, so as to be able to solve the problems faced, and further improve employee performance and organizational performance. In all situations the leader has a very important role. The leader is a symbol, role model, motivator as well as a source of effect, which can direct various activities and resources to achieve his goals. The ability to unite human aspects becomes its own difficulties, and this is one of the tasks of a leader.

A research on leadership style on work discipline has been studied by Sutarmaningtyas (2014) which shows that transformational and transactional leadership styles both have positive and significant effects on employee work discipline, because the higher of leader' ability to develop transformational and transactional leadership, the better of effect in improve employee work discipline. A research conducted by Pratama (2012) shows a significant effect between autocratic leadership styles on work discipline. This result is supported by research conducted by Kurniadi (2013) which shows that transformational, transactional and autocratic leadership styles have a positive effect on work discipline.

Today, the latest developments see employees not as mere resources, but rather as capital or assets for institutions or organizations. Therefore, then a new term emerged outside HR (Human Resources), namely HC or Human Capital. Here, human resources is seen not merely as a main asset, but as an asset that is valuable and can be multiplied, developed (compared to investment portfolios) and also not vice versa as liability. In this perspective human resources as an investment for institutions or organizations are more prominent.

In time, achievements and skills will be difficult to obtain if only rely on what he has without ever undergoing the process of debriefing or development. Thus, leadership support in the management and development of human resources is very influential in the effectiveness and efficiency of an organization. Also, 
organizational culture has a significant role in improving employee performance. Organizational culture functions as a binding on all components of the organization, determines identity, energy, motivators, and can be used as guidelines for members of the organization.

Organizational culture is an adhesive tool that is able to bring organizational groups closer, which can be a positive energy that is able to bring the organization to a better direction. Leadership and organizational culture have a very close relationship, because each leader has a different leadership style that will ultimately form an organizational culture. Therefore, it is often said that organizational culture reflects leadership in the organization; it is like two sides of a coin that have the same value.

\section{Method of Research}

The research is an explanatory research that explains the causal relationship of variables through hypothesis testing. It uses a qualitative approach by looking at phenomena and to measure the effect of leadership competency and quality in human resource management.

\section{Relationship between Leadership Competency and Work Quality}

Leadership is an ability to influence groups towards achieving goals. It can be interpreted as the use of power and influence to direct the activities of followers towards the achievement of goals. Thus, it can be concluded that leadership is an ability to influence others to want to work together in achieving the goals.

A result of regression analysis indicates that leadership competency and quality simultaneously have a significant positive effect on competitive and sustainable human resource management. Culture is born from its leaders and leaders reflect the culture of organization. Like two sides of a coin in one coin. Each leader has a different temperament which later will create a culture that reflects his personality. Where, the leader upholds the values of discipline so that he can make himself as a change agent to influence employees in improving discipline, namely the enforcement of employee discipline penalties through bureaucratic culture.

In addition, the leader is very close to the employees, helping to create a comfortable and close atmosphere at work so that employees make themselves role models in building a supportive culture that is reflected in a fairly solid sense of family. Not only being a change agent and role model in building a bureaucratic and supportive culture, but more than that being able to become a pilot project in self-development through sharing knowledge, sharing work experience, so as to encourage employees to further enhance their potential. This is reflected through competitive culture (see Figure 1).

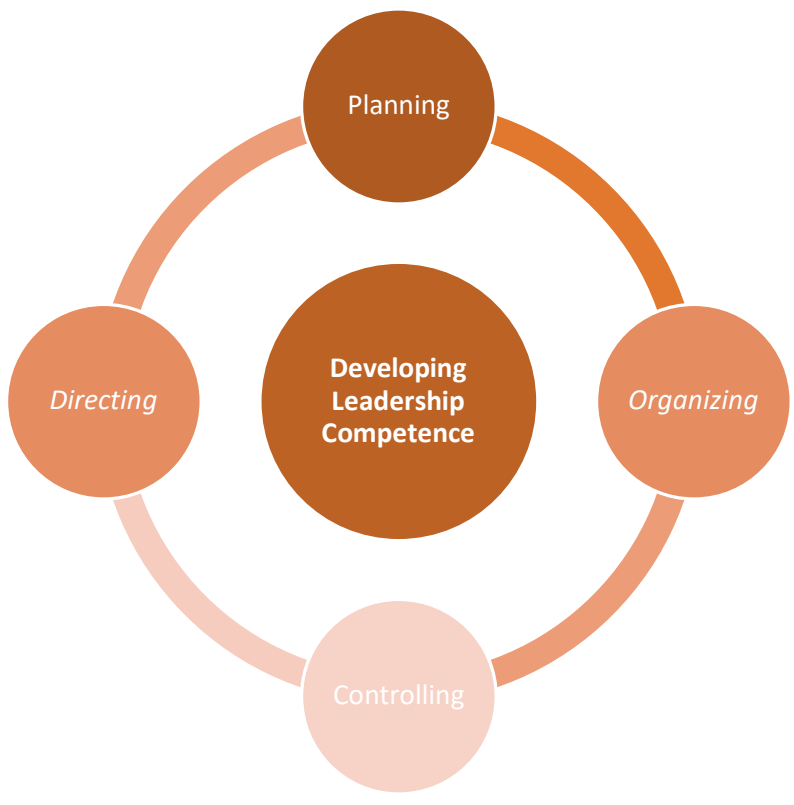

Figure 1. Managerial function of leadership

As results, it shows that the leadership style is directly proportional to the competence and quality, as well as the transformational leadership styles. Leaders often try to provide guidance and motivation but this has not yet made employees aware of the importance of performance, because in this case what employees need is not just guidance and motivation but what they need most is "vitamins" in the form of finance to improve employee 
performance.

Work discipline is one of the important functions of human resource management and a key to the realization of goals, because without discipline it is difficult to realize maximum goals (Sedarmayanti, 2010). According to Rivai (2010), work discipline is a tool used by managers to communicate with employees so that they are willing to change a behavior and as an effort to increase awareness and willingness to observe all company regulations and applicable social norms. Further, work discipline can be done by giving sanctions in the form of punishment and warning in order to create a deterrent effect for employees and so that they do not repeat their mistakes again and can work better (Iswara, 2013).

Really, leaders have a very important role in upholding the discipline of an institution or organization. A leader is someone who has the ability to influence others to be able to do things according to their wishes and in accordance with organizational goals. Leadership is not only meant to influence someone to achieve goals but also is a process of motivating employee behavior in efforts to improve the group and work discipline of company employees.

Leaders need 3 (three) characteristics of leadership to be able to lead a large number of people and have a different mindset, including transformational leadership, transactional leadership and autocratic leadership. To create an orderly and disciplined atmosphere in the work environment, the employees can not only be done by appointing others to optimally transform organizational resources (transformational leadership) and also cannot be done by simply approaching, encouraging and giving rewards in return (transactional leadership ), but also must be with absolute leadership and the threat of punishment (autocratic leadership) so that each employee has a fear and can comply with what is ordered and said by his leadership.

Transformational leadership is guidance through individual consideration, intellectual stimulation, inspiration, and the ideal influence of managers (McColl-Kennedy \& Anderson, 2005). According to Pranantio et al. (2013), transformational leadership is an ethical leadership style that involves the ability of a leader to promote intellectual stimulation through inspiration. Transformational leadership refers to leaders who succeed in moving employees beyond self-interest directly through the influence of ideal or charisma, inspiration, intellectual stimulation, or individual consideration. Meanwhile Rafferty \& Griffin (2004), states that transformational leaders motivate employees to achieve performance beyond expectations by transforming the attitudes, beliefs and values of employees in order to obtain compliance. In a research as conducted by Kurniadi Ramli (2013), stated that in the transformational leadership style with work discipline is very positively and significantly related. The higher of perception of transformational leadership style, the higher of work discipline and conversely the lower of perception of transformational leadership style, the lower of existing work discipline.

In this case, as observation conducted by the author on transformational leadership, it is still deemed to have lacked a direct approach and motivated his employees and less successful in moving employees to work optimally. For example, if employees experience difficulties and obstacles in their duties, the leader does not want to come down directly to provide encouragement and direction to his subordinates. Leaders tend to let these employees to solve the problems they face alone.

The results of research indicate that the transformational leadership style has a positive and significant effect on work discipline, where a leader who adopts a transformational leadership style has higher employee work discipline. Transactional leadership style has a positive and significant effect on work discipline. This is because the leader who applies the transactional leadership style increase work discipline of employee. The autocratic leadership style has a positive and significant effect on work discipline. This shows that the leader who applies autocratic leadership style, the higher of employee work discipline.

\section{Conclusion}

It showed that leadership competency and quality simultaneously had a significant positive effect on competitive and sustainable human resource management. Human resource development in organizations is an integral form of business development, both concerning human resources as individuals and as a system, as well as organizations as human resource containers to meet the needs of any organization. The approach of human capital quality emphasizes the human function (employee) as a main determinant of organizational success besides financial, technological, material. Weak capacity of human resource quality will have implications for the ability to create performance, the creative power and sustainability of an organization in facing the era of competition and global challenges.

\section{References}

Ellitan, L. (2002). Praktik-praktik pengelolaan sumber daya manusia dan keunggulan kompetitif berkelanjutan. Jurnal manajemen dan Kewirausahaan, 4(2), 65-76

Kurniadi Ramli. 2013. Pengaruh Persepsi Gaya Kepemimpinan Transformasional Terhadap Disiplin Kerja Karyawan. Jurnal Manajemen dan Bisnis. Vol : 1. No : 1. 
McColl-Kennedy, J. R., \& Anderson, R. D. 2005. Subordinatemanager gender combination and perceived leadership-style influence on emotions, self- esteem and organizational commitment. Journal of Business Research, 58 (2), pp :115-125.

Pratama, Christian Yogi. 2012. Pengaruh Gaya Kepemimpinan Otokratis Terhadap Kepuasan Kerja. Jurnal Sosial dan Industri Psikologi. Vol : 1. No : 2 .

Sutarmaningtyas, Ari Nurul. 2014. Pengaruh Gaya Kepemimpinan Transformasional dan Transaksional Terhadap Disiplin Kerja Karyawan. Jurnal Administrasi Bisnis. Vol. 14 No.2.

Sedarmayanti. 2010. Manajemen Sumber Daya Manusia. Bandung : Refika Adiutama.

Rivai, Veithzal. 2010. Manajemen Sumber Daya Manusia Untuk Perusahaan : Dari Teori ke Praktik. Jakarta : Rajawali Pers.

Iswara Pramudita. 2013. Pengaruh Gaya Kepemimpinan, Budaya Organisasi Dan Lingkungan Kerja Fisik Terhadap Disiplin Kerja Karyawan. Fakultas Ekonomi. Universitas Udayana.

Pranantio, Sani., Hidayat, Wahyu., Widiartanta. 2014. Pengaruh Motivasi, Gaya Kepemimpinan Transaksional dan Budaya Organisasi Terhadap Kinerja Karyawan Pada PT. Nyonya Meneer. Jurnal Ilmu Administrasi Bisnis.

Rafferty, Alannah E. Dan Mark A.griffin. 2004. Dimensions of Transformational Leadership : Conceptual and Empirical Extensions. International Journal of The Leadership Quarterly. Vol. 15 (2),329-354.

Nunung Ghoniyah, Masurip, 2011, Peningkatan Kinerja Karyawan Melalui Kepemimpinan, Lingkungan Kerja Dan Komitmen, Jurnal Dinamika Manajemen, Vol. 2, No. 2, pp: 118-129.

Almasri, M. Nazar. 2016. Manajemen Sumber Daya Manusia: Imlementasi Dalam Pendidikan Islam, Kutubkhanah: Jurnal Penelitian sosial keagamaan, Vol.19, No.2 